\title{
AES BI OFLUX
}

\section{Advances in Environmental Sciences International J ournal of the Bioflux Society}

\section{Landfills as anthropogenic landforms in urban environment from Neamt county}

\author{
Florin-C. Mihai, Liviu Apostol, Adrian Ursu, Pavel I chim
}

\author{
“Alexandru I oan Cuza “University, Department of Geography, Iaşi, Romania. \\ Corresponding author: F.-C. Mihai, mihai.florin86@yahoo.com
}

\begin{abstract}
Landfills are the most common and easiest methods to dispose the municipal waste in Romania and still prevails in current waste management options. This type of critical infrastructure was designed to dispose urban waste generated over years or even decades and ultimately led to create new landforms in urban landscape. On the other hand, these sites are major sources of complex pollution unfulfilling EU regulations, being scheduled to be closed. This paper aims to analyze landfills as anthropogenic landforms by applying GIS techniques emphasizing them in a geographical context and not only in situ. The location of these sites usually on alluvial plains of rivers leading to positive landforms that may change hydrogeomorphology dynamics or to be exposed to the floods. The other side, their location in hilly or mountainous regions increase vulnerability to other geomorphological process (gully erosion, landslide). Also, the extension of human settlements and land use is influenced by the presence of such a site either it is closed. The implications of these landforms are varied and must be linked to geographical realities from around. Thus, the mapping of these anthropogenic landforms contribute to a better understanding of the systemic interactions from local environment. This approach may be an important tool for EIA studies, in the process of rehabilitation, post-monitoring and reintegration of these landfills.
\end{abstract}

Key Words: landfill, anthropogenic landform, urban areas, GIS techniques.

Introduction. Literature revealed the fact cities from various geographical regions are exposed to pollution due to improper waste disposal of municipal waste particularly in developing countries (Khajuria et al 2010; Kumar et al 2009; Taseli 2007; Chen 2010; Tadesse et al 2008). Waste management systems have not received as much attention in the city planning process as other sectors like water or energy (Zaman \& Lehmann 2011). In this context, landfills are sources of complex pollution in urban areas. Furthermore, partial access of urban population to waste collection services or improper distribution of waste management facilities contribute to the illegal dumping (Mihai et al 2011; Mihai et al 2012a; Ichinose \& Yamamoto 2011; Rojas \& Zambrano 2008). The regulations on municipal waste management systems aim to divert the waste from landfilling by supporting the new concept of waste hierarchy. Waste prevention is on the top of this hierarchy and landfilling is the last option but the reality is exactly the opposite on the field. Waste prevention is scarcely implemented or absent in most EU members (Salhofer et al 2008; Gentil et al 2011) and landfilling still prevails (Manzzati \& Zoboli 2008) despite of various technical solutions (Pires et al 2011). Socio-economic disparities across EU-27 reflect different options adopted between Northern-Southern and/or Western-Eastern countries (Mihai \& Apostol 2012). Waste management is a complex sector because it involves legislative (laws, rules, guidelines on management, responsibilities and competences), environmental (resources use and their optimal management), economic (reuse, disposal and tariff) and urban planning aspects (Bamonti et al 2011). New models are proposed to help decision makers of a municipality to establish an integrated waste management system for urban areas (Costi et al 2004; Guariso et al 2009). Romania, as all new members, has difficulty to pass from a traditional waste management system based on landfiling to a sustainable and integrated system. National, regional and local waste management plants establish a schedule (2005-2017) for closure of all non-compliant landfills, these sites being replaced with 
regional sanitary landfills (1-2 for each county) and transfer stations (which may have sorting and composting facilities). Old sites were operational since 1960 with no proper infrastructure to protect the local environment. Pollution from landfills increases closer to cities or surrounding rural areas.

Landfill, beside a toxic potential source, is an ordinary anthropic landform like irrigation channels, dams, protective embankments, quarries, tunnels, roads or agricultural terraces which can disturb the dynamic equilibrium of geosystem (Ursu et al 2011). This paper aims to outline the territorial and environmental implications of these critical infrastructure as anthropogenic landform at local scale using GIS techniques.

Material and Method. Environmental impact assessment studies and risk assessments should not ignore the temporal and spatial variations of various landfill characteristics (Butt el al 2008) and it must be examined in a geographical context (Mihai 2012). New approaches or assessment tools are used in landfill studies such as remote sensing (Son et al 2011) or spatial analysis with GIS techniques (Sumathi et al 2008; Zamorano et al 2008; Leao et al 2004). The paper perfomed a GIS analysis for three non-compliant urban landfills from Neamt County. These sites are located in various geographical context as follows: Roman (corridor valley of Moldova river), Bicaz (mountain region in the proximity of Bistriţa river), Târgu Neamt (hill region). Methodology of mapping products involved the use of digital datasets such as SRTM (Shuttle Radar Topography Mission), topographic survey for Roman landfill (CJ Neamt) orthophotoplans (2005) and 1:25000 topographic map of Romania in Gauss-Kruger projection. For processing and querying of these spatial data it has been used TNTMips software 7.0. Achievement of digital maps concerning on the one hand the land use in the proximity of these sites and on the other hand the digital elevation model for Roman landfill was obtained through onscreen vectorization method of level curves and linear interpolation using the GIS soft. In order to examine the direct influences of a non-compliant landfill site to surroundings it used three buffers zones such as 250/500/1000 m. Spatial implications of a landfill site may be significant in the radius of $0.5 \mathrm{~km}$ or moderate until $1 \mathrm{~km}$ and lower for over 1 $\mathrm{km}$. The paper also analysis one the one hand the amounts of waste disposed in these sites during 2004-2010 and on the other side the disadvantages of the traditional waste management systems from this period.

Results and Discussion. Improper management of wastes can lead to serious health threats as a result of fires, explosions, and contamination of air, soil, and water (Demirbas 2011). Non-compliant landfills in the proximity of urban areas such as Roman, Târgu Neamt and Bicaz led to complex pollution. Traditional waste management systems from Romanian cities is still based on mixed waste collection and landfilling. This options prevail in all cities from Neamt county during 2004-2010 (Table 1); only Piatra Neamt had a slight decrease of landfilling in last years due to implementation of an integrated waste management systems supported by ISPA funds. This system since 2007 provides separate collection (paper/cardboard, PET/plastics, biodegradable fractions) sorting and composting facilities, crushing plants (construction and demolition wastes) and sanitary landfill. Also there are two collection points (Darmăneşti and Mărăței neighborhoods) where WEEE, bulky waste and hazardous municipal waste could be collected.

Table 1

Share of landfilling in urban waste management systems

\begin{tabular}{cccc}
\hline Landfilling (\%) & 2004 & 2007 & 2010 \\
\hline Piatra Neamt & 99.96 & 88.74 & 88.22 \\
Roman & 99.91 & 99.915 & 99.77 \\
Târgu Neamt & 100 & 100 & 100 \\
Bicaz & 100 & 100 & 100 \\
Roznov & 100 & 100 & 100 \\
\hline
\end{tabular}


On the contrary, Roznov city had no waste management services during 2004-2010, waste generated being improperly disposed in open dumps. Starting with 2011 the city was covered by separate collection and transfer station has been constructed through PHARE-CES 2005 programme. The EU acquis imposes the closure of these non-compliant landfills, deadlines stipulated in HG no. 349/2005, deadlines being 2010 for Bicaz landfill and July 2012 for Roman and Târgu Neamt. Also dumpsites (< 1ha) from small cities such as Roznov should be closed and rehabilitated (compacted and soil covered) until 16 July 2009 as same for rural areas (Mihai et al 2012b).

Roman landfill. The site is located on floodplain of Moldova river, in the south-west of the Roman city near to Siret confluence. It is the largest landfill from this study ( $5 \mathrm{ha}$ ), design capacity is $900000 \mathrm{~m}^{3}$ built in 1980 being operational for 32 years. The lack of waterproofing system and short distance from landfill site to Moldova river $(<10 \mathrm{~m})$ favored river pollution. Also, high hydrostatic level may facilitated the leachate infiltration into groundwater. Leachate infiltration into groundwater can affects the aquifers that supply the near households with drinking water from wells. This dumpsite is most vulnerable to flooding from study area due to geographical location in a lowland area in the proximity of two major rivers such as Moldova and Siret. Such large landfills develop a specific ecosystem (microflora, microfauna, crows, flies, mosquitoes, rodents, dogs, etc.) due to high share of biodegradable waste from total amounts of municipal waste disposed. This ecological niche can affect the balance of ecosystem from surrounding areas particularly for agricultural lands. Also, a landfill site favors the spread of pathogenic agents threatening livestock and/or human health. Most exposed to this risk are members of informal sector which collect metals and others recyclables from landfill to sell them to recycling companies. Buffers areas (diameter of 250/500 and 1000 meters) revealed the fact that built-up areas are also exposed to pollution due to proximity of this improper site, as it is shown in Figure 1.

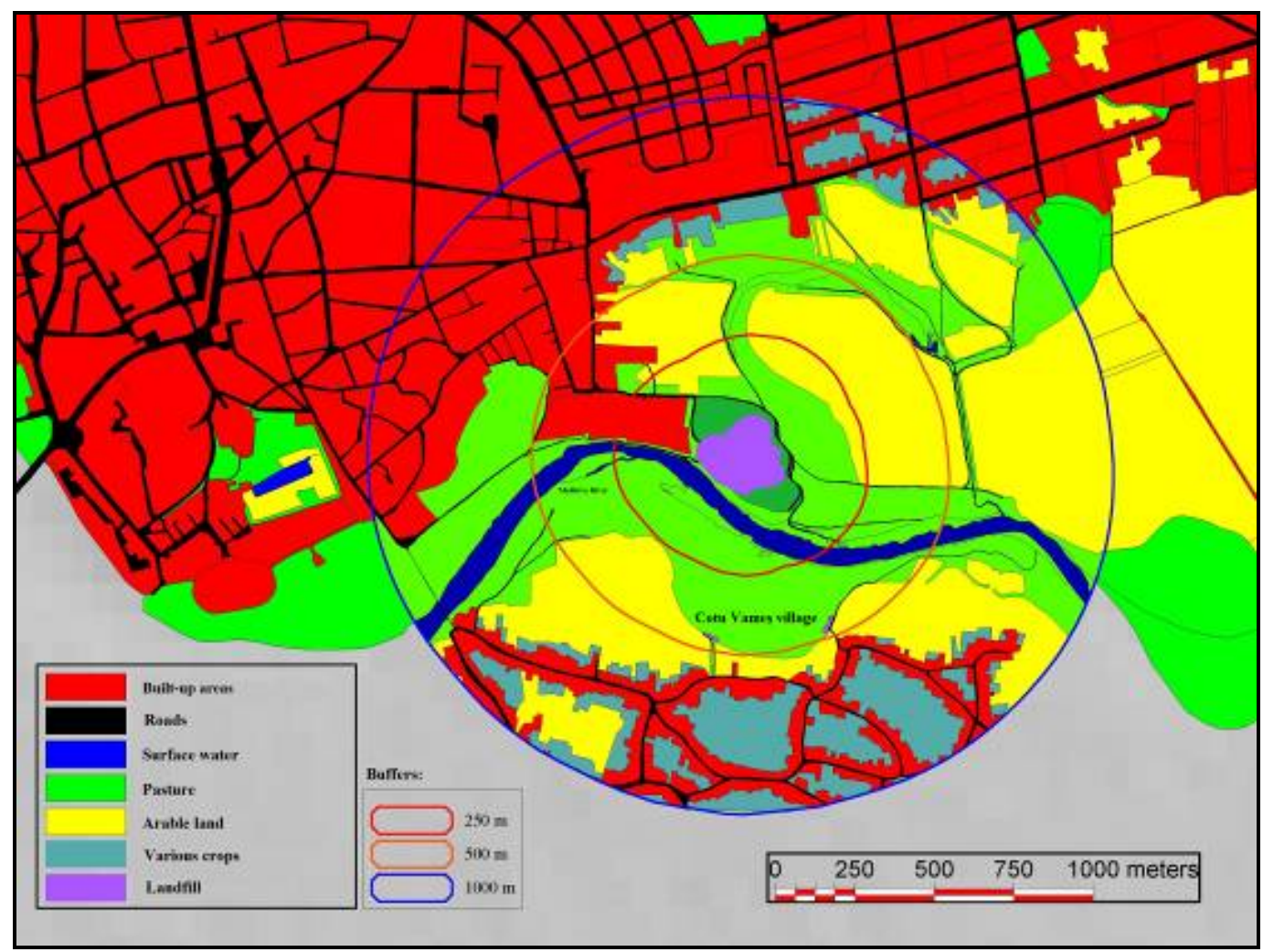

Figure 1. Land use in the proximity of Roman landfill.

Biodegradable waste prevails and the biogas is accumulating inside the landfill. Poorlycompacted waste favors the oxygen penetration and spontaneous combustion may occur releasing toxic gases, dust and soot which cover the surrounding area. 
Landfill emissions carried by wind (dominant direction North-South) may be deposited on arable land in the proximity of city and also for Cotu Vameş village. The toxic potential is higher particularly for various crops from gardens inside the buffer area $(1 \mathrm{~km})$. Protected area from ecological network of Natura 2000 such as Lunca Siretului Mijlociu (ROSPA0072) is in proximity of this site. This open site could be also a toxic food source for certain protected species which crosses this area. During operational period of this old site a new landform takes shape in local landscape (Figure 2).

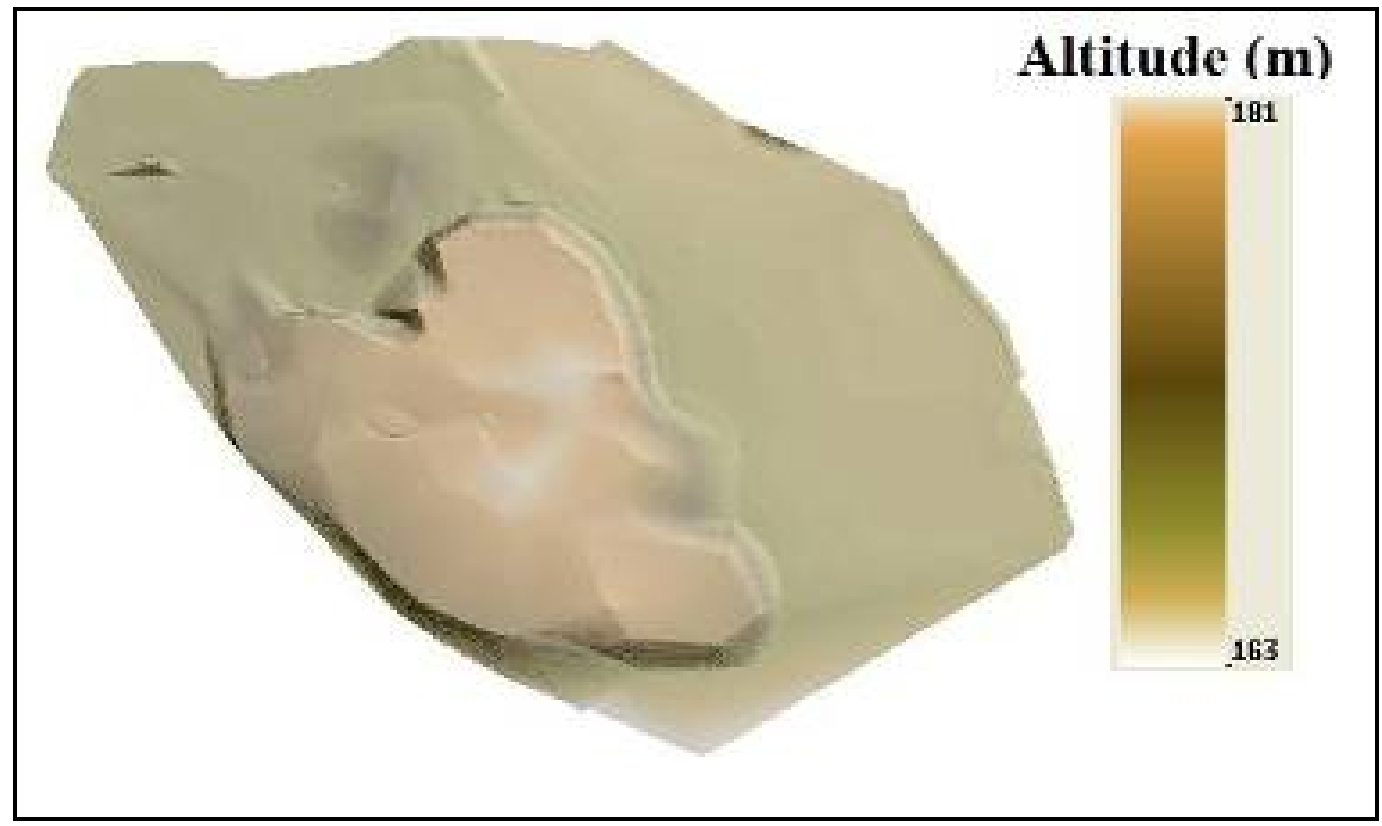

Figure 2. Modelling of Roman landfill as anthropogenic landform (3D).

This anthropogenic landform is better highlighted in lowlands such as floodplain of Moldova river. These landforms modified the balance of the old and natural ecosystem imposing various changes at local scale. Frequently such landfills are best examples for studying human influences on urban environment.

Bicaz landfill. The city is situated in eastern Carpathian Montains at the confluence of Bicaz and Bistriţa rivers in the proximity of Izvoru Muntelui lake. The landfill is located in the north of the city, district Dodeni, on Bistriţa river terrace (left side) dowstream the dam as shown in Figure 3.

This site is the smallest from study area ( $2 \mathrm{ha}$ ), design capacity for $450000 \mathrm{~m}^{3}$, built in 1962 being operational for 47 years. Geographical barriers of this mountain region did not provide many options for the location of such site. This location does not comply the minimum distance from residential buildings (at least $1 \mathrm{~km}$ ) being to close one the one hand to the blocks of Dodeni district from right side and on the other hand to some households from left side of Bistriţa river.

Air currents channeled on Bistrița valley (North to South) led, during operational period of this site, to transportation emissions (such as $\mathrm{CO}_{2}, \mathrm{SO}_{x}, \mathrm{CH}_{4}$, dust) from landfill site to the city. Others climatic factors such as a higher rainfall in this mountain region and also snow melting in early spring led to a surplus of water that crossed the landfill generating a greater quantities of leachate that could reach into Bistriţa river. Regarding the vulnerability to the floods, the Izvoru Muntelui dam on Bistrița river is intended to mitigate these natural hazards in upstream, so only a strong flood on Izvorul Muntelui stream may affect this site. In order to minimize the geomorphological processes such as landslides or gully erosion, the slope terrace of Bistriţa river near the dumpsite was afforested. Although Ceahlău National Park limits are more than $1 \mathrm{~km}$ away from this site, buffer region (forest areas) is recently included in the Nature 2000 network as SPA and $\mathrm{SCl}$ site according to Birds and Habitats Directives. Closure of this landfill contribute 
on the one hand to improvement of urban environment and on the other hand to local biodiversity protection.

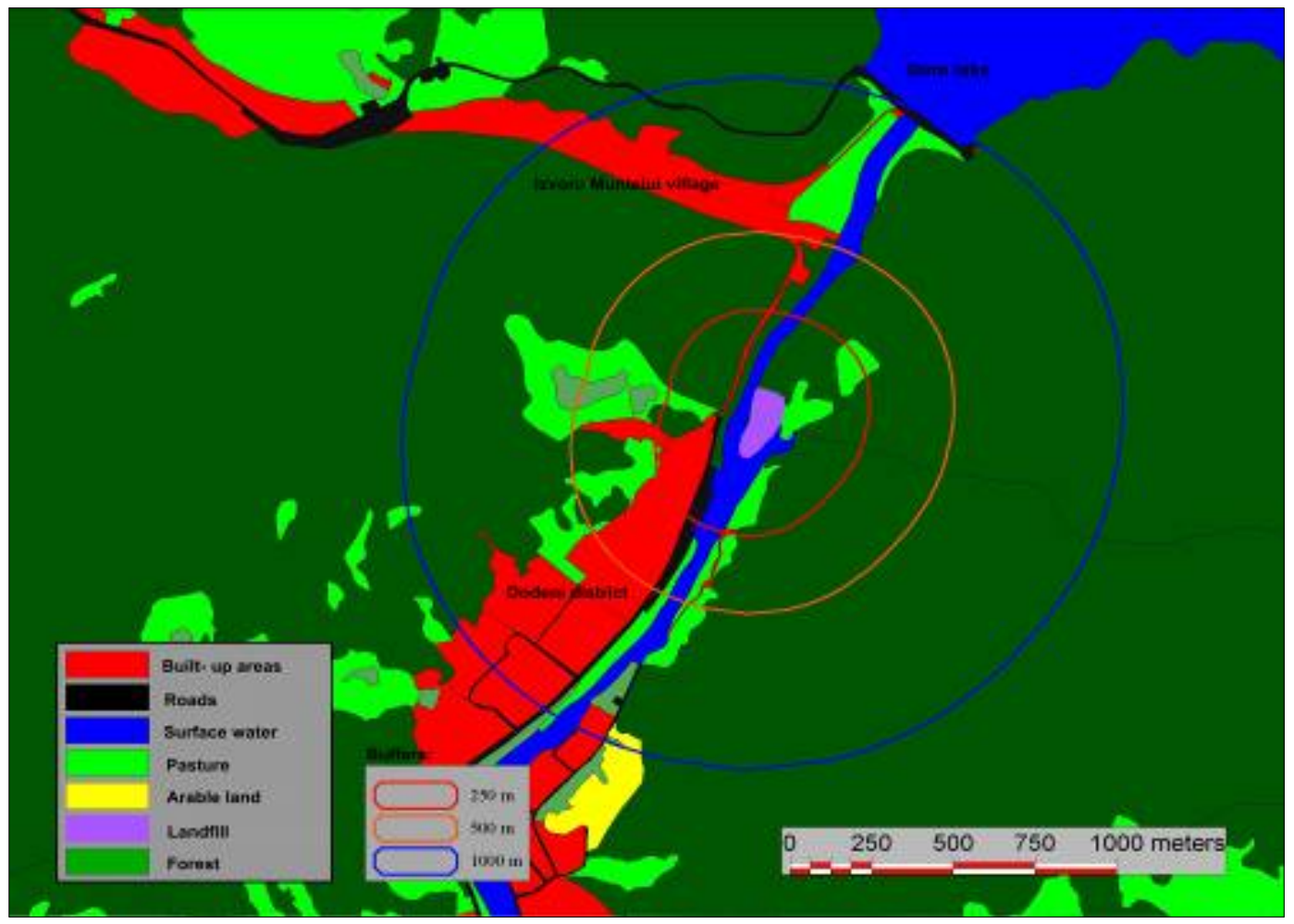

Figure 3. Land use in the proximity of Bicaz landfill.

Târgu Neamt landfill. The site is located in a hilly region between two localities, Târgu Neamt city and Oglinzi village from Răuceşti commune in a less populated area. Although distance from the last households of Târgu Neamt city is below $1 \mathrm{~km}$, the location of this site is a better choice than the other two cases because the city is less exposed. Built-up area of city (households) is not included in the buffer area of $500 \mathrm{~m}$ or covers a small area in buffer of $1 \mathrm{Km}$ (Figure 4). Also, no industrial facilities are located in the proximity of this landfill but there is a national road which connects the Neamt County to Suceava County (Fălticeni city). Furthermore, the site is located on a land with no agricultural use (pasture) and it is not exposed to floods of major rivers such as Moldova (Roman) or Bistrita (Bicaz). However, the landfill extended on a torrent valley (NW) that during the intense rains favored transportation of leachate to Slatina stream. Also, this site is located at a distance of 1-1.5 km from limits of Vânători Natural Park and to Oglinzi resort.

Demographic differentiations between these cities are reflected in the amounts of municipal waste disposed on these sites. However, it is a constant trend of waste disposed in Târgu Neamt and Bicaz landfills unlike Roman city where are significant oscillations during 2004-2010 as it shown in Figure 5. Major decrease in the period 20072010 can not be attributed to reducing landfilling in the context of poor recycling facilities but rather of a progressive improvement of the data which are ordinary overestimated by waste operators (data for 2010 is probably the closest to reality). Because the landfills operators have no weighing system, the data for these sites are volumetric estimated $\left(\mathrm{m}^{3}\right)$ then converted to tonnes taking into account the household waste density (300-350 $\mathrm{kg} / \mathrm{m}^{3}$ for Romania). Waste operators report these data to local (county) environmental protection agency. This procedure is improving year by year due to EU regulations on waste statictics.

Better knowledge of complete MSW cycle dynamics could allow to reach the waste management goals that are at present still far from being achieved in many EU countries (Bianchini et al 2011). Reliable data it is an important tool in waste management 
planning and it must be related to geographical conditions of study area (Chowdhury 2009; Passarini et al 2011; Keser et al 2012). Directive 99/31/EC required EU Members to create strategic plans for the reduction of biodegradable MSW previously going to landfills and defined the targets for biodegradable waste landfill disposal (Magrinho et al 2006). This fraction has an important share in municipal waste composition in Romania an also for Neamt County over $50 \%$. Waste disposal in these non-compliant landfills was done by simply stacking without any sort or neutralization, including biodegradable waste.

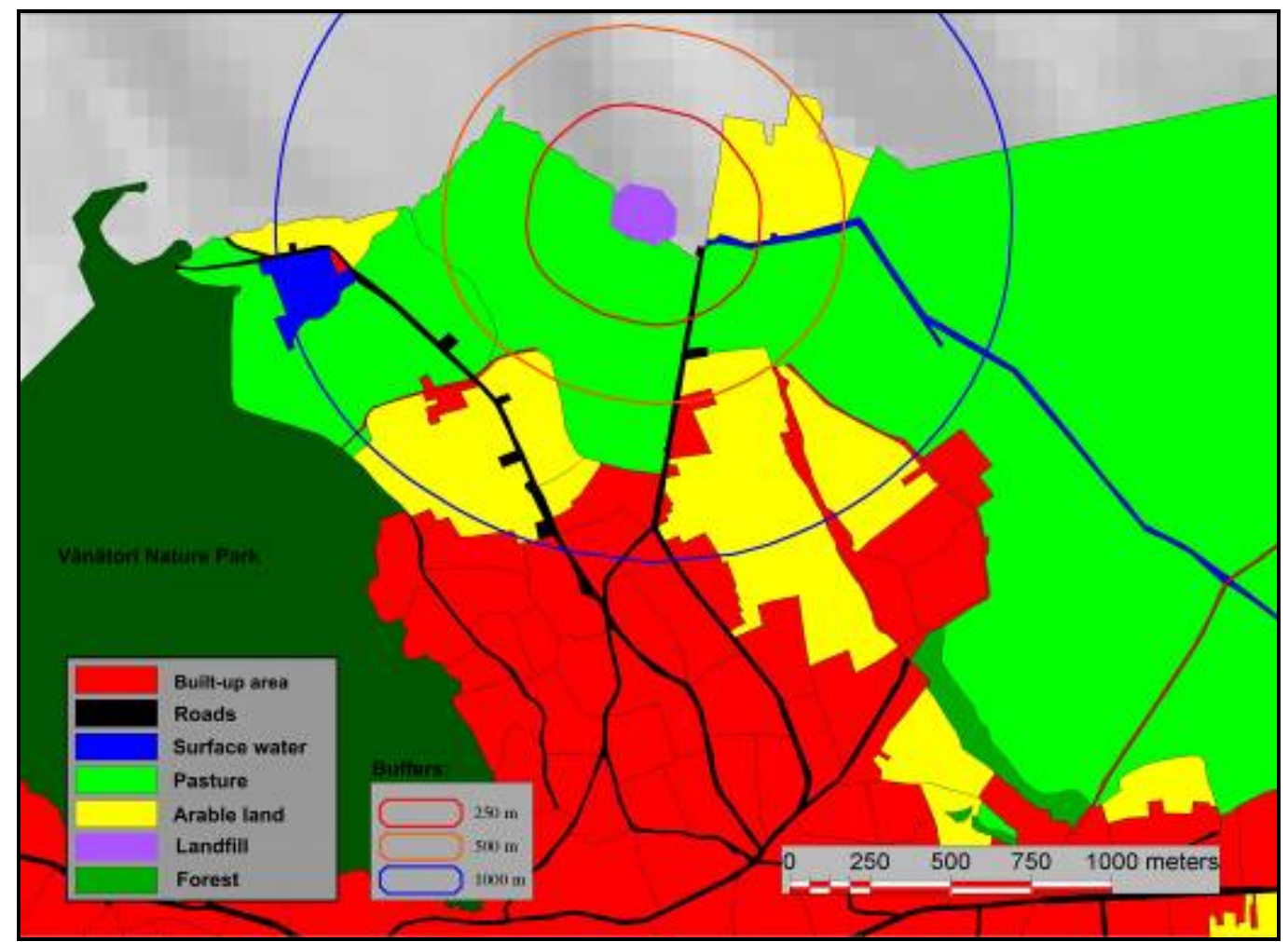

Figure 4. Land use in the proximity of Târgu Neamt landfill.

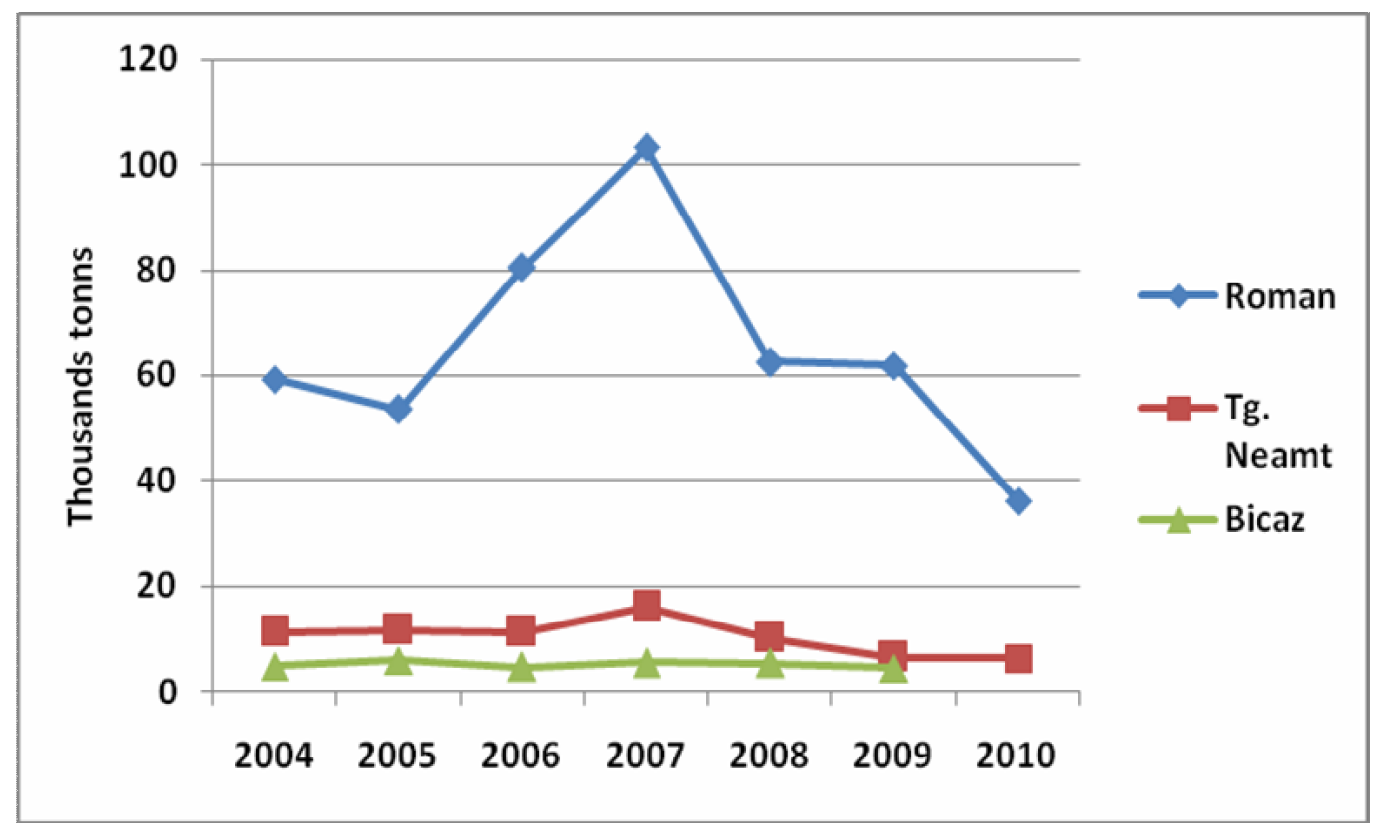

Figure 5. Estimated amounts of municipal waste disposed in non-compliant landfills. 
Construction and demolition waste were used for maintenance of the access road inside the landfill site and as coating layer of waste. Methane accumulation led to spontaneous combustion of solid waste (e.g. Roman city landfill). Furthermore, these sites have no facility for leachate treatment polluting the hydrographic network (Figure 6). Location of these sites in the proximity of major rivers such as Moldova (Roman city landfill) and Bistriţa (Bicaz city landfill) increases the vulnerability to flooding. On this issue, Laner et al (2009) developed a methodology to assess the potential impact of floods for old and controlled sites from Austria.

Such approaches are necessary for Romania too, because landfills are ordinary located on floodplains of rivers. In this regard, Bistriţa river was recently dammed on the area of sanitary landfill which serves the Piatra Neamt city

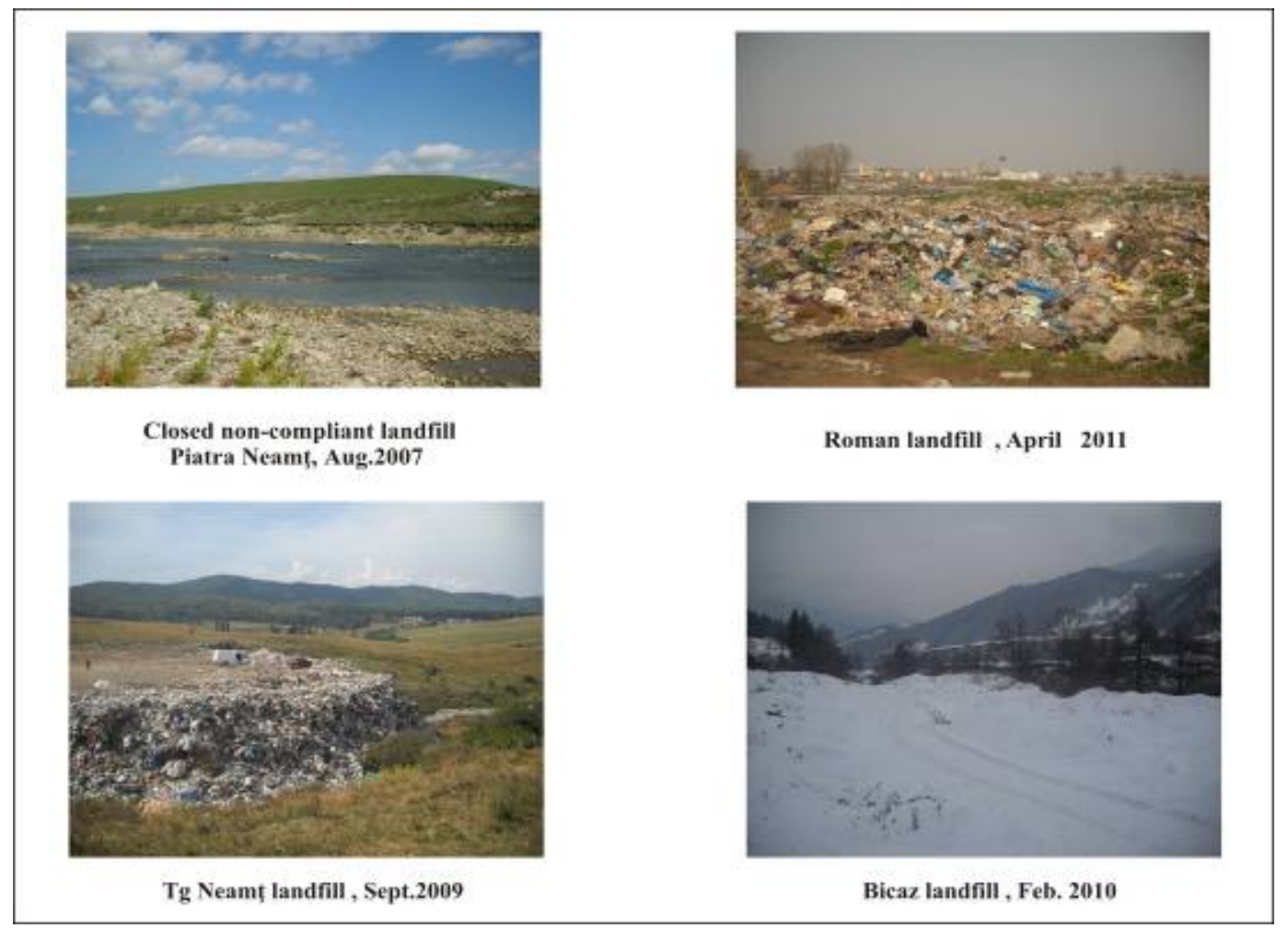

Figure 6. Non-compliant landfills from urban areas of Neamt County.

Mixed waste collection led to disposal of various fractions in these sites such as household and similar waste, street waste, gardens waste, bulky waste, construction and demolition waste, WEEE, hazardous municipal waste (batteries, accumulators, detergents \& cleaning fluids, oils and other liquids, pesticides etc.), sludges from wastewater treatment plants which increased the toxic potential. By the adoption of EU regulations on municipal waste management, these fractions have emerged as specific waste streams which should be collected and treated separately. Old landfills of Roman and Târgu Neamt cities also received the household and similar waste collected from rural areas in the proximity. This practice has spread particularly after the closure of rural dumpsites (16 July 2009) until these sites will be closed (deadline July 2012) to be replaced on the one hand by a new regional landfill located in Girov commune and on the other hand by transfer stations from Târgu Neamt city and Cordun commune.

Conclusions. Poor facilities inside these old sites favored the pollution of urban environment, this fact being also influenced by local geographical conditions. Also these non-compliant landfills usually are located in the proximity of built-up areas or arable lands. Cities often ignored the waste management issue by promoting the traditional systems based on mixed collection and landfilling. New regulations impose an integrated waste management system which changes the current waste management planning. Landfill sites must be linked to a geographical context for a holistic approach. In this 
context, GIS techniques are a necessary tool for EIA studies completing the common methodologies described in literature.

\section{References}

Bamonti S., Bonoli A., Tondelli S., 2011 Sustainable waste management criteria for local urban plans. Procedia Engineering 21:221-228.

Bianchini A., Pellegrini M., Saccani C., 2011 Material and energy recovery in integrated waste management system - an Italian case study on the quality of MSW data. Waste Management 31:2066-2073.

Butt T. E., Lockley E., Oduyemi K. O. K., 2008 Risk assessment of landfill disposal sites state- of-the-art. Waste Management 28: 952-964.

Chen C. C., 2010 Spatial inequality in municipal solid waste disposal across regions in developing countries. International Journal of Environmental Science and Technology 7(3): 447-456.

Chowdhury M., 2009 Searching quality data for municipal solid waste planning. Waste Management 29:2240-2247.

Costi P., Minciardi R., Robba M., Rovatti M., Sacile R., 2004 An environmentally sustainable decision model for urban solid waste management. Waste Management 24:277-295.

Demirbas A., 2011 Waste management, waste resource facilities and waste conversion processes. Energy Conversion and Management 52:1280-1287.

Gentil E. C., Gallo D., Christensen T. H., 2011 Environmental evaluation of municipal waste prevention. Waste Management 31:2371-2379.

Guariso G., Michetti F., Porta F., Moore S., 2009 Modelling the upgrade of an urban waste disposal system. Environmental Modelling and Software 24:1314-1322.

Ichinose D., Yamamoto M., 2011 On the relationship between the provision of waste management service and illegal dumping. Resource and Energy Economics 33:7993.

Keser S., Duzgun S., Aksoy A., 2012 Application of spatial and non-spatial data analysis in determination of the factors that impact municipal solid waste generation rates in Turkey. Waste Management 32:359-371.

Khajuria A., Yamamoto Y., Morioka T., 2010 Estimation of municipal solid waste generation and landfill area in Asian developing countries. Journal of Environmental Biology 31(5):649-654.

Kumar S., Bhattacharyya J. K., Vaidya A. N., Chakrabarti T., Devotta S., Akolkar A. B., 2009 Assessment of the status of municipal solid waste management in metro cities, state capitals, class I cities, and class II towns in India: an insight. Waste Management 29:883-895.

Laner D., Fellner J., Brunner P. H., 2009 Flooding of municipal solid waste landfills - an environmental hazard? Science of the Total Environment 407:3674-3680.

Leao S., Bishop I., Evans D., 2004 Spatial-temporal model for demand and allocation of waste landfills in growing in urban regions. Computers, Environment and Urban Systems 28:353-385.

Magrinho A., Didelet F., Semiao V., 2006 Municipal solid waste disposal in Portugal. Waste Management 26:1477-1489.

Mazzanti M., Zoboli R., 2008 Waste generation, waste disposal and policy effectiveness. Evidence on decoupling from the European Union. Resources, Conservation and Recycling 52: 1221-1234.

Mihai F.-C., 2012 Geography of waste as a new approach in waste management study. Papers of "Dimitrie Cantemir" Geographical Seminar 33: 39-46.

Mihai F.-C., Ghiurcă A. A., Lămăşanu A., 2011 Estimation of urban waste generated and uncollected in Romania. Analele Universităţii Oradea, Fascicula: Protecţia Mediului 17(2): 719-724.

Mihai F.-C., Apostol L., 2012 Disparities in municipal waste management across EU-27. A geographical approach. Present Environement and Sustainable Development 6(1): 169-180. 
Mihai F.-C., Lămăşanu A., Apostol L., 2012a Regional disparities in urban population access to sanitation services. Case study: Romania. Mediterranean Journal of Social Sciences, Special issue 3(6): 273-279.

Mihai F.-C., Apostol L., Ghiurcă A. A., Lămăşanu A., Bănică A., 2012b Geographical distribution of rural dumpsites in North-East Region from Romania. Conference Proceedings of $12^{\text {th }}$ International Multidisciplinary Scientific GeoConference SGEM 2012, 17-23 J une 2012, Albena, Bulgaria, 5: 447-452.

Passarini F., Vassura I., Monti F., Morselli L., Villani B., 2011 Indicators of waste management efficiency related to different territorial conditions. Waste Management 31: 785-792.

Pires A., Martinho G., Chang N. B., 2011 Solid waste management in European countries: a review of systems analysis techniques. Journal of Environmental Management 92: 1033-1050.

Rojas C. R. I., Zambrano C. E. A., 2008 Urban observatories opportunities for environmental monitoring: solid wastes. Waste Management 28:540-544.

Salhofer S., Obersteiner G., Schneider F., Lebersorger S., 2008 Potentials for the prevention of municipal solid waste. Waste Management 28:245-259.

Son S., Wang M., Shon J. K., 2011 Satellite observations of optical and biological properties in the Korean dump site of the Yellow Sea. Remote Sensing of Environment 115: 562-572.

Sumathi V. R., Natesan U., Sarkar C., 2008 GIS-based approach for optimized siting of municipal solid waste landfill. Waste Management 28:2146-2160.

Tadesse T., Ruijs A., Hagos F., 2008 Household waste disposal in Mekelle city, Northern Ethiopia. Waste Management 28:2003-2012.

Taseli B. K., 2007 The impact of the European Landfill Directive on waste management strategy and current legislation in Turkey's Specially Protected Areas. Resources, Conservation and Recycling 52:119-135.

Ursu A., Chelaru D. A., Mihai F.-C., Iordache I., 2011 Anthropogenic landform modeling using GIS techniques case study: Vrancea region. Geographia Technica 1:91-100.

Zaman A., Lehmann S., 2011 Urban growth and waste management optimization towards 'zero waste city'. City, Culture and Society 2:177-187.

Zamorano M., Molero E., Hurtado A., Grindlay A., Ramos A., 2008 Evaluation of a municipal landfill site in Southern Spain with GIS-aided methodology. Journal of Hazardous Materials 160:473-481.

*** GD no.349 of 21 April 2005 on the landfill of waste, completed by GD no. 210/2007 [in Romanian].

*** Neamt County Council, 2005 Integrated Waste Management System. Closure of uncompliant landfill (Phare Project 2005 /017-553.04.03/08.01) [in Romanian].

Received: 20 February 2013. Accepted: 25 February 2013. Published online: 09 aprilie 2013.

Authors:

Florin-Constantin Mihai, “Alexandru Ioan Cuza “University, Department of Geography, 700505, Iaşi, 20 A Carol

I Blvd, Romania, e-mail: mihai.florin86@yahoo.com

Liviu Apostol, “Alexandru Ioan Cuza “University, Department of Geography, 700505, Iaşi, 20 A Carol I Blvd,

Romania, e-mail: apostolliv@yahoo.com

Adrian Ursu, "Alexandru I oan Cuza “University, Department of Geography, 700505, Iaşi, 20 A Carol I Blvd,

Romania, e-mail: ursu_v_adrian@yahoo.com

Pavel Ichim, “Alexandru Ioan Cuza “University, Department of Geography, 700505, Iaşi, 20 A Carol I Blvd,

Romania, e-mail: pavel_ichim@yahoo.com

This is an open-access article distributed under the terms of the Creative Commons Attribution License, which permits unrestricted use, distribution and reproduction in any medium, provided the original author and source are credited.

How to cite this article:

Mihai F., Apostol L., Ursu A., Ichim P., 2013 Landfills as anthropogenic landforms in urban environment from Neamt county. AES Bioflux 5(2): 100-108. 